\title{
Nemi kromoszóma-rendellenességek vizsgálata gyermekkorban
}

\author{
Pinti Éva dr. - Lengyel Anna dr. - Sallai Ágnes dr. \\ Fekete György dr. - Haltrich Irén dr.
}

Semmelweis Egyetem, Általános Orvostudományi Kar, II. Gyermekgyógyászati Klinika, Budapest

Bevezetés: A nemi kromoszóma-rendellenességek időben történő diagnózisa a prevenció, a családtervezés és a megfelelő kezelés érdekében egyaránt fontos.

Célkitüzés: A nemi kromoszómaaberrációkkal kapcsolatos fenotípus, a diagnóziskori életkor és a terápiás lehetőségek közötti összefüggések tanulmányozása.

Módszer: A Semmelweis Egyetem II. számú Gyermekgyógyászati Klinikájának citogenetikai szakrendelésén 2009 és 2014 között az anamnézis, családfaelemzés, fizikális vizsgálat, kariotipizálás és fluoreszcens in situ hibridizáció módszerével vizsgált és nemi kromoszóma-rendellenességgel diagnosztizált 51 gyermek adatainak feldolgozása.

Eredmények: 41\%-ban Turner-, 18\%-ban Klinefelter-, 10\%-ban dupla-Y-, 6\%-ban tripla- és poli-X-szindrómát, 19\%ban egyéb gonáddiszgenezist, 6\%-ban más rendellenességet azonosítottunk. A diagnóziskori átlagéletkor: Turner- és Klinefelter-szindróma 10 év, egyéb gonáddiszgenezisek 9 év, 46,XX,t(X;10) 17 év, a többi eltérés esetében 1-2 év. Következtetések: A nemi kromoszómák numerikus aberrációi gyakoribbak a strukturális rendellenességekhez képest. A Klinefelter-, a tripla- és a poli-X-szindróma gyermekkorban aluldiagnosztizált. A Turner-szindróma és az egyéb gonáddiszgenezisek esetében az optimális terápia és a társuló kórképek prevenciója érdekében korábbi diagnózis szükséges. Ebben a korszerú praenatalis diagnosztikai módszerek és a házi gyermekorvosok ilyen irányú aktivitása segíthet.

Orv Hetil. 2018; 159(27): 1121-1128.

Kulcsszavak: nemi kromoszómaaberrációk, citogenetika, nemi fejlődés zavarai

\section{Examination of sex chromosome abnormalities in childhood}

Introduction: Early diagnosis of sex chromosome abnormalities is important because of prevention, family planning and optimal therapy.

Aim: Investigation of the relationship between phenotype, age at time of diagnosis and therapeutic options in sex chromosome aberrations.

Method: Processing data of 51 children with sex chromosome abnormalities who were diagnosed between 2009 and 2014 and examined at the 2nd. Department of Pediatrics, Semmelweis University, by the methods of anamnesis, family tree analysis, physical examination, karyotype analysis and fluorescent in situ hybridisation.

Results: $41 \%$ of the patients were diagnosed with Turner-, $18 \%$ with Klinefelter-, $10 \%$ with double-Y-, $6 \%$ with tripleand poly-X-syndrome, $19 \%$ with other gonadal dysgenesis and $6 \%$ with other abnormality. The average age at diagnosis: Turner- and Klinefelter-syndrome 10 years, other gonadal dysgenesis 9 years, 46,XX,t $(\mathrm{X} ; 10) 17$ years, other abnormalities 1-2 years.

Conclusions: Numerical aberrations of the sex chromosomes are more common than structural aberrations. Klinefelter-, triple- and poly-X-syndromes are underdiagnosed in childhood. Early diagnosis of Turner-syndrome and other gonadal dysgenesis is necessary to optimise therapy and prevent associated diseases. This can be achieved by modern prenatal diagnostic methods and targeted activity of family pediatricians.

Keywords: sex chromosome aberrations, cytogenetics, disorders of sex development

Pinti É, Lengyel A, Sallai Á, Fekete Gy, Haltrich I. [Examination of sex chromosome abnormalities in childhood]. Orv Hetil. 2018; 159(27): 1121-1128.

(Beérkezett: 2018. február 2.; elfogadva: 2018. március 7.) 


\section{Rövidítések}

$\mathrm{AFP}=$ alfa-fetoprotein; $\beta$-hCG = humán koriongonadotropin béta-alegysége; $\mathrm{CBS}=$ (cord blood sampling) köldökzsinórvér-mintavétel; CVS = (chorionic villus sampling) chorionboholy-mintavétel; DNS = dezoxiribonukleinsav; DYS132 = Y-kromoszóma-szekvencia; DYZl = Y-kromoszóma-ismétlődési szekvencia-1; DYZ3 = Y-kromoszóma-ismétlődési szekvencia-3; FISH = fluoreszcens in situ hibridizáció; FTS = (foetal tissue sampling) magzatiszövet-mintavétel; GAC = genetikai amniocentesis; inhA $=$ inhibin- $\mathrm{A} ; \mathrm{NT}=$ (nuchal translucency) tarkóredő-vastagság; PAPP-A = terhességasszociált plazmaprotein-A; PCR = polimeráz-láncreakció; $\mathrm{SHOX}=$ alacsonynövésért felelős homeoboxgén; SRY = nemet meghatározó Y-régió; uE3 = konjugálatlan ösztriol; $\mathrm{UH}=$ ultrahang; $\mathrm{ZFY}=$ cinkujjas Y-kromoszóma-fehérje

A gonosomák aberrációi a leggyakoribb kromoszómarendellenességek. Újszülöttkori gyakoriságuk 2,5\%, ezen belül a számbeli eltérések $2 \%$-et, míg a szerkezetiek 0,5\% ${ }^{2}$-et tesznek ki [1]. Etiopatogenezisükból adódóan a világ bármely táján közel azonos gyakorisággal fordulnak elő, amit több szakirodalmi adat is alátámaszt $[2,3]$. A nemi kromoszómaaberrációk túlnyomó részét kitevő eltérések incidenciája újszülötttkorban a következő: Turner-szindróma [4] 1 : 2000-3000, Klinefelter-szindróma 1 : 500-600, tripla-X-, valamint dupla-Y-szindróma esetén $1: 900-1200[2,3]$.

A kromoszómák eltérései és azok következményei minden életszakaszban meghatározóak, azonban az élet- kor előrehaladtával más-más aspektusaik jutnak kiemelt szerephez. A gyermekekre gyakorolt hatásaik különösen fontosak, mivel erre az életszakaszra intenzív és látványos szomatikus és pszichomotoros fejlődés jellemző.

Nemcsak a gyakoriság és a terápiás hatékonyság miatt érdemes ebben a korcsoportban a kórképek minél korábbi felismerésére törekedni. A genommutációk életreszólóan és szerteágazóan meghatározzák az egyén biológiai fejlődését és pszichoszociális állapotát, emellett pedig hatással vannak a későbbi családtervezésre. Az orvoslásban a leghatékonyabb beavatkozás a prevenció szintjén lehetséges, így korai diagnózis birtokában a még ki nem bontakozott eltéréseket is célzottan kereshetjük, és időben felismerve kezelhetjük.

Vizsgálatunk célja a gyermekkorban fellelhető nemi kromoszómaaberráció-típusok, illetve azok egymáshoz viszonyított gyakoriságának meghatározása a rendelkezésre álló klinikai adatok alapján.

Kíváncsiak voltunk, hogy az egyes kórképcsoportokban a diagnózis mikor születik meg, a terápia idôben megkezdhető-e, és a betegségek milyen eljárásokkal ismerhetők fel korábban.

\section{Módszer}

Munkánk során a 2009 és 2014 közötti időszakra vonatkozóan dolgoztuk fel a Semmelweis Egyetem II. számú Gyermekgyógyászati Klinikája citogenetikai szakrendelésének keretében nemi kromoszóma-rendellenességgel

1. táblázat | Nemi kromoszóma-rendellenességek karyotypus szerinti megoszlása

\begin{tabular}{|c|c|c|c|c|}
\hline Kromoszóma-rendellenesség & Karyotypus & Irodalmi adat a megoszlásról [3] & \multicolumn{2}{|c|}{ Vizsgált betegek szám } \\
\hline \multirow[t]{8}{*}{ Turner-szindróma } & $45, \mathrm{X}$ & $60 \%$ & 11 & $50 \%$ \\
\hline & $46, \mathrm{X}, \mathrm{i}(\mathrm{Xq})$ & $15 \%$ & 3 & $13,5 \%$ \\
\hline & $45, \mathrm{X} / 46, \mathrm{XX}$ & \multirow{4}{*}{$\begin{array}{l}\text { Mozaicizmus: } \\
15 \%\end{array}$} & 3 & \multirow{4}{*}{$27 \%$} \\
\hline & $45, \mathrm{X} / 46, \mathrm{X}, \mathrm{r}(\mathrm{X})$ & & 1 & \\
\hline & $45, \mathrm{X} / 46, \mathrm{X}, \operatorname{del}(\mathrm{Xq}) / 46, \mathrm{XX}$ & & 1 & \\
\hline & $45, \mathrm{X} / 47, \mathrm{XXX} / 46, \mathrm{XX}$ & & 1 & \\
\hline & $46, \mathrm{X}, \mathrm{del}(\mathrm{Xq})$ & - & 1 & - \\
\hline & $46, \mathrm{X}, \mathrm{del}(\mathrm{Xp})$ & $10 \%$ & 1 & $4,5 \%$ \\
\hline \multirow[t]{2}{*}{ Klinefelter-szindróma } & $47, \mathrm{XXY}$ & $85 \%$ & 9 & $100 \%$ \\
\hline & Mozaicizmus & $15 \%$ & 0 & - \\
\hline Tripla-X-szindróma & $47, \mathrm{XXX}$ & \multirow{10}{*}{ Nem áll rendelkezésre } & 2 & \\
\hline Poli-X-szindróma & $48, \mathrm{XXXX}$ & & 1 & \\
\hline \multirow[t]{2}{*}{ Dupla-Y-szindróma } & $47, \mathrm{XYY}$ & & \multicolumn{2}{|l|}{4} \\
\hline & $47, \mathrm{XYY} / 46, \mathrm{XY}$ & & \multicolumn{2}{|l|}{1} \\
\hline Y-kromoszóma szerkezeti rendellenessége & $46, \mathrm{X}, \mathrm{del}(\mathrm{Yq})$ & & \multicolumn{2}{|l|}{1} \\
\hline Gonosoma-autoszoma transzlokáció & $46, \mathrm{XX}, \mathrm{t}(\mathrm{X} ; 10)$ & & \multicolumn{2}{|l|}{1} \\
\hline \multirow[t]{4}{*}{ Egyéb gonáddiszgenezisek } & 46,XX férfifenotípus & & \multicolumn{2}{|l|}{1} \\
\hline & 46,XY női fenotípus & & \multicolumn{2}{|l|}{6} \\
\hline & 45,X/46,XY női fenotípus & & \multicolumn{2}{|l|}{2} \\
\hline & $45, \mathrm{X} / 46, \mathrm{XY}$ férfifenotípus & & \multicolumn{2}{|l|}{1} \\
\hline
\end{tabular}


diagnosztizált gyermekek kivizsgálásának és kezelésének adatait.

A vizsgálati algoritmus kezdeti lépését az anamnézis kikérdezése képezte, amit a családfa felvétele és elemzése követett. Ezek kiemelten fontosak a kockázati tényezók feltérképezésében, valamint a differenciáldiagnosztika tekintetében. Kockázatot jelent az előrehaladott anyai ( $\geq 35$ év) vagy apai ( $\geq 45$ ) életkor, a rokonházasság, a családban előforduló genetikai betegség, terhelő szülészeti kórelőzmény, kóros ultrahanglelet, fokozott kockázatra utaló anyai szérummarkerszint, a magzatvíz mennyiségi eltérései, bizonyos gyógyszerek szedése, egyes várandósság alatti fertőzések, valamint a vegyszer- és sugárterhelés [5]. A fizikális vizsgálat során a megtekintés különös jelentőségü [6]. Fontos, hogy egy-egy eltérés önmagában sosem specifikus és nem kellőképpen szenzitív. Mind a fenotípust, mind a funkcionális eltéréseket átfogóan kell értékelni.

A nemi kromoszóma-rendellenességek genetikai diagnózisának alapja a konstitucionális karyotypus meghatározása [7-9]. A rejtett mozaicizmusok feltárására vagy a mozaicizmus fokának pontos meghatározására a fluoreszcens in situ hibridizáció (FISH) [10-12] a legalkalmasabb technika. A vizsgálati mintát általában a perifériás vérből származó lymphocytasejtek képezik, azonban egyes esetekben - amikor a kórkép nincs összhangban a lymphocyták karyotypusával - indokolt más szövetek (fibroblastsejtek, szájnyálkahártyasejtek vagy vizelet-laphámsejtek) kromoszómastatusát is felmérni.

\section{Eredmények}

A hat év alatt igazolt ötvenegy nemi kromoszóma-rendellenességet kördiagramon foglaltuk össze (1.ábra), közülük nyolcat praenatalis vizsgálati eredmény postnatalis validálásaként, míg a többit a születés után valamely anomália kivizsgálása kapcsán diagnosztizáltuk.

A klinikai szindrómákon belül feltüntettük a különböző karyotypus-alcsoportokat (1. táblázat). Turnerszindrómában a 45,X-kromoszóma-készlettel járó typusos forma volt a leggyakoribb (50\%), ezt követték a különféle mozaicizmusok (27\%), majd a 46,X,i(Xq) szerkezeti rendellenesség (13,5\%).

Míg a Turner-szindróma klasszikus 45,X-karyotypusú eseteiben a kórkép genetikai diagnózisa nem ütközött nehézségekbe, addig a mozaikos és a szerkezeti rendellenességgel járó formák pontos felderítése a hagyományos G-sávos citogenetikai vizsgálattal 11 esetben nem volt lehetséges. Az alacsony százalékban előforduló vagy kevert mozaikos formákat interfázis-FISH-vizsgálattal pontosítottuk. Ilyen eset volt például a 45,X[10]/47,XXX[5]/46,XX[320] (2. A ábra); a $48, X X X X$ (2. $B$ ábra) vagy a $46, \mathrm{XX}, \mathrm{t}(\mathrm{X} ; 10)(\mathrm{ql} 3.3 ; \mathrm{ql1})$ (2. $C$ ábra) és a 46,X,i $(\mathrm{X})(\mathrm{q} 10)$ (2. $D$ ábra) szerkezeti rendellenesség.

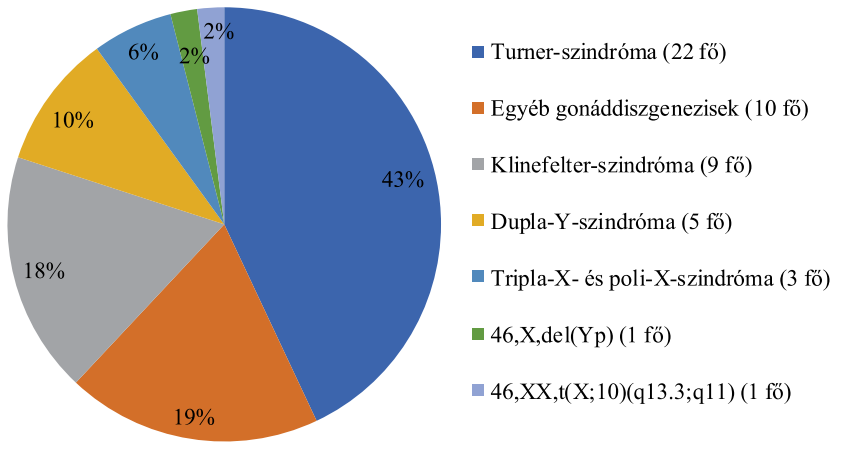

1. ábra $\mid$ A vizsgált nemi kromoszóma-rendellenességek (51fő) egymáshoz viszonyított gyakorisága

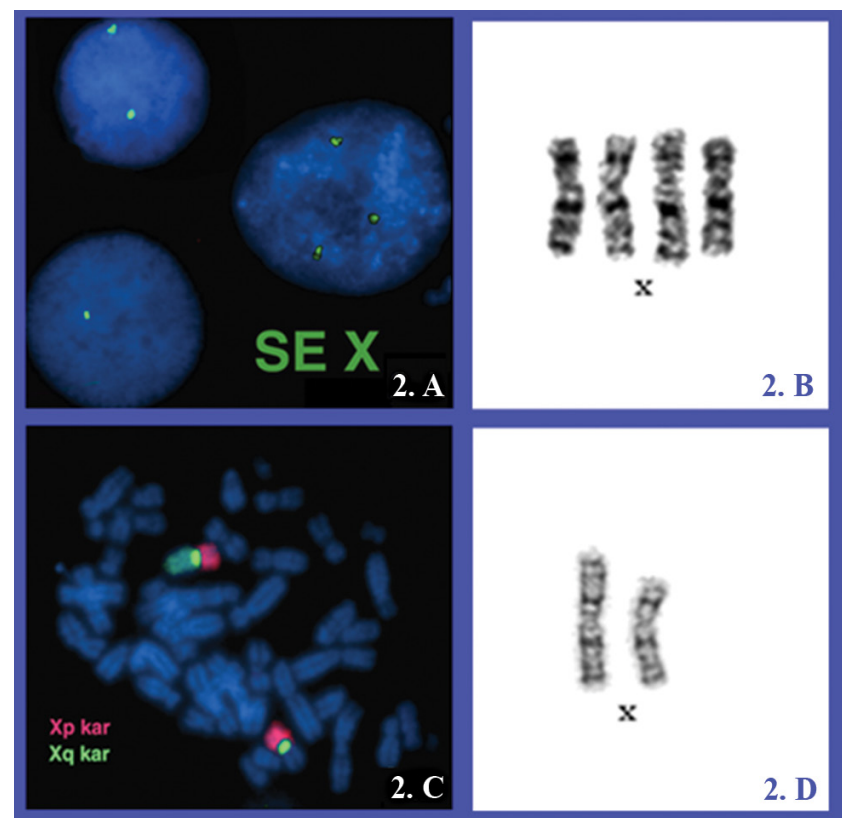

2. ábra 2. A ábra: Mozaikos Turner-szindróma FISH mintázata 45,X[10]/47,XXX[5]/46,XX[320] karyotypussal

2. B ábra: Poli-X-szindróma $48, \mathrm{XXXX}$ karyotypussal (parciális kariogram)

2. C ábra: Nemi kromoszóma-autosoma transzlokáció FISH képe $46, \mathrm{XX}, \mathrm{t}(\mathrm{X} ; 10)(\mathrm{q} 13.3 ; \mathrm{ql1})$ karyotypussal

2. D ábra: Turner-szindróma 46,X,i $(\mathrm{X})(\mathrm{q} 10)$ karyotypussal (parciális kariogram)

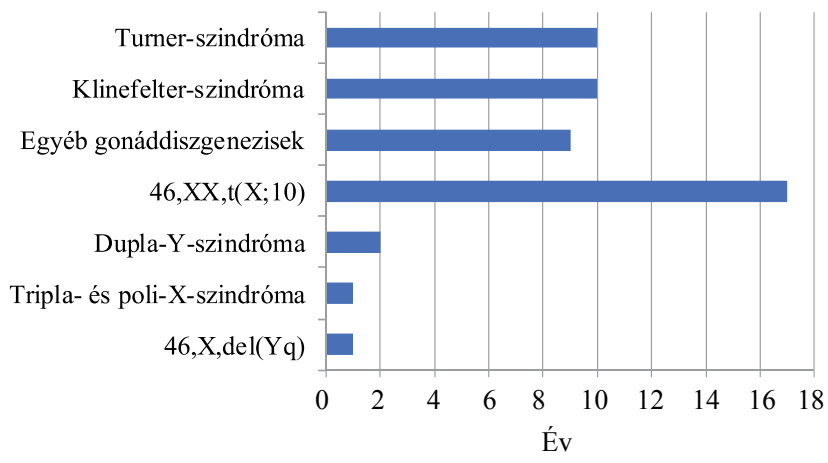

3. ábra Átlagéletkor a diagnosztizálás idejében 
A Klinefelter-szindrómás betegek között csak 47,XXYkaryotypusú formát diagnosztizáltunk, mozaicizmus nem fordult elő.

Az egyéb gonáddiszgenezisek csoportjában többféle genotípust azonosítottunk. A 45,X/46,XY kevert gonáddiszgenezisek [13] esetében mind női, mind férfifenotípusban fellelhető volt csíkgonád és/vagy diszgenetikus here.

A másik célkitűzésünk a vizsgálat idejében megfigyelt életkor meghatározása, az egyes kórképek felismerésével kapcsolatos nehézségek és a megkésett diagnózis esetleges kockázatainak feltárása volt (3. ábra). A legkorábban diagnosztizált csoportokat az Y-kromoszóma szerkezeti rendellenessége [14], a poli-X- és a tripla-X-, valamint a dupla-Y-szindrómák képezték, melyeket már a magzati genetikai diagnózist követően csecsemő- és kisdedkorban sikerült kimutatni. Egyetlen gyermek volt 48,XXXXkaryotypusú (2. Bábra), ami tiszta formában meglehetősen ritka. A Klinefelter- és a Turner-szindróma diagnosztizálása esetén egyaránt magasabb átlagéletkor volt megfigyelhető, amely mindkét csoportban 10 évnek adódott.

A betegségek azonosítása során a sokszor igen enyhe és nem specifikus tünettan nehezítette a kromoszómarendellenességgel járó állapotok időben történő felismerését. A késői diagnózis következtében a gyermekek egy részénél nem valósulhatott meg az optimális nemihormon-szubsztitúció, és a rendellenességekhez társuló eltérések prevenciója is sok esetben késlekedett.

\section{Megbeszélés}

A vizsgált betegek esetében a gonosomák eltéréseinek nagyobb hányadát a számbeli rendellenességek tették ki a szerkezeti eltérésekkel szemben. A szakirodalmi gyakorisági adatoknak a kapott eredményekkel való összehasonlíthatósága érdekében az egyes nemi kromoszómaaberrációk egymáshoz viszonyított arányát vettük alapul.

\section{Turner-szindróma}

A Turner-szindróma 45,X-kromoszóma-készlettel járó typusos formája a szakirodalomban közölt arányhoz képest csaknem 10\%-kal ritkábban fordult elő, a 46,X,i(Xq)karyotypusú forma közel azonos, míg a mozaikos formák csaknem kétszer annyi esetben kerültek diagnosztizálásra [15].

Az X-kromoszóma rövid karjának deletiós rendellenessége nem érte el a szakirodalom alapján elvárt gyakoriságot. Két esetben az X-kromoszóma hosszú karjának deletiója volt fellelhető egy tiszta és egy mozaikos formában.

A 46,X,i (Xq)-karyotypusú strukturális aberráció (2. D ábra) fennállásakor a különféle autoimmun - föként a pajzsmirigyet érintő - betegségek [16] gyakrabban fordulnak elő a 45,X-Turner-genotypushoz viszonyítva.
A Turner-szindrómások diagnóziskor rögzített átlagéletkora a többi kórképcsoporthoz viszonyítva magasabb, 10 év volt. A növekedési és serdülőkori zavarok kezelése, valamint a társuló egyéb szervi eltérések keresése és nyomon követése, a szövődmények megelőzése korábbi diagnózist igényel. A leggyakoribb tünet az alacsony testmagasság [17], ami akár 20-22 cm-rel is elmaradhat a várható végleges testmagasság átlagától. Esetükben a humán rekombináns növekedési hormon pótlása [18] már 2-3 éves kortól ajánlott. Ezzel akár 7-9 $\mathrm{cm}$-rel is növelhető a várható felnőttkori átlagos testmagasság, ami a magyarországi Turner-szindrómás populációt tekintve $150-155 \mathrm{~cm}$-nek felel meg. Bár a végleges testmagasság az egészségesekéhez képest így is alulmarad, a 9 éves kor feletti késői azonosítással és terápiával már csak maximum 3-5 cm-es növekedési nyereség várható. A kezelés - hatékonyságának fokozása céljából 8-12 éves kor között oxandrolon anabolikus szteroiddal egészíthető ki. A terápia ellenjavallt kezeletlen pajzsmirigy-alulmúködés, csökkent glükóztolerancia, cukorbetegség, a beleegyezés vagy kooperáció hiánya (a beteg, a szülők vagy a gondviselők részéről), a mellékhatásként fellépő csípőízületi károsodás, valamint az évi 2,0 cm-t el nem érő növekedési ütem esetében.

A női nemi hormonok szubsztitúciója a serdülőkor indukálásától 50 éves korig javasolt.

Az ösztrogén pótlását 11 évesnek megfelelő csontkortól alacsony dózissal célszerú kezdeni és fokozatosan emelve 2-3 éven keresztül folytatni. A progeszteronnal történő ciklikus hormonpótlás az endometriumcarcinoma profilaxisa érdekében történik. Ezt a kezelést az első áttöréses vérzés jelentkezésétől, de legkésőbb az ösztrogén adásának kezdetétől számítva 2-3 év múlva szükséges bevezetni. A női nemi hormonok adásának célja a másodlagos nemi fejlődés biztosítása és az ösztrogénhiánnyal járó betegségek (csontritkulás, érelmeszesedés) kockázatának csökkentése [19]. A női nemi hormonok fontos szerepet töltenek be az agy kognitív (hippocampus), emocionális (amygdala), valamint szociális funkciókért és szexuális aktivitásért (bypothalamus) felelős részeinek megfelelő érésében is $[20,21]$.

Az infertilitás megoldására a petesejt-donáció és in vitro fertilizáció szolgálhat segítségül. A szindrómával rendelkező várandósoknál gyakoribbak a különböző szülészeti és kardiológiai szövődmények [22, 23], ezért alapos és körültekintő várandósgondozás indokolt. Bernard és mtsai 2016-ban 480 Turner-szindrómás beteg adatait elemezve vizsgálták a spontán terhességek előfordulását és kimenetelét. Összesen 27 betegnél $(5,6 \%) 52$ spontán terhesség jött létre, amivel jól korreláló prediktív faktor volt a spontán menstruáció és a mozaicizmus. A terhességek több mint fele (58\%) szüléssel végződött; a spontán vetélések száma (31\%) meghaladta az átlagpopulációét (15\%). A 17 leányból kettő született Turner-szindrómával. Négy terhesség (13,3\%) szövődött várandósság indukálta magasvérnyomás-betegséggel [22]. A spontán vetélés mellett a különféle malformációk és kromoszó- 
maanomáliák jelenthetnek veszélyt a magzatra [23]. Az anyai diabetes következtében az újszülött súlya lehet nagyobb vagy a cardiovascularis betegségek miatt a normálisnál (2500-4000 g) kisebb is [23].

A Turner-szindrómás betegeknél a kardiológiai betegségek (magas vérnyomás, kéthegyü aortabillentyü, a felszálló aorta dilatációja, aortaszúkület) prevalenciája 25$50 \%$. Mivel az aorta dissectiójának kockázata fennáll a terhesség kezdetén normális aortaátmérőnél is, növekedésének ellenőrzése szükséges [24, 25]. Az aortadissectio vagy -ruptura miatti halálozás kockázata $2 \%$ feletti [23].

A cukorbetegség és az autoimmun pajzsmirigybetegség nagyobb kockázata miatt szükséges a vércukorprofil és a pajzsmirigyfunkció szoros követése [23].

A kognitív funkciók nem minden esetben és nem megegyező mértékben érintettek. Legfőképp a performációs készségek és a szenzomotoros koordináció károsodhat $[19,26]$, így tanácsos ezek egyénre szabott fejlesztése.

A kórképpel társuló, szerteágazó eltérések [27] miatt rendszeres multidiszciplináris gondozás javasolt. Ennek koordinálása, a családdal történő szoros együttmúködés elérése - a páciens fokozott pszichoszociális sérülékenységére való különös tekintettel - leginkább a házi gyermekorvos és a családorvos feladata.

\section{Klinefelter-szindróma}

A szakirodalom szerint a Klinefelter-szindróma élveszülöttekre vonatkoztatva négyszer-hatszor gyakoribb a Turner-szindrómánál, ami esetünkben nem igazolódott. A Turner-szindróma megközelítóleg kétszer gyakrabban volt azonosítható, mint a Klinefelter-szindróma. Az utóbbi kórkép aluldiagnosztizáltságának hátterében a gyermekkorban megnyilvánuló enyhébb tünetek állhatnak, a többi eset valószínúleg a felnőttkori infertilitás kivizsgálása kapcsán kerülhet azonosításra [28].

A Klinefelter-szindrómások átlagéletkora a vizsgálat idejében meghaladta az egyéb kórképekkel rendelkezőkét, ami a serdülőkor táján látványosabban kibontakozó panaszokkal magyarázható.

A társuló kórképek megelőzésében és kezelésében a pubertáskor kiemelt jelentőségü. A tesztoszteronszint emelkedésének elmaradása és annak hatása a férfi nemi hormon szupplementációjával korrigálható [29], aminek következtében az emlőnövekedés és a csontritkulás kialakulásának mértéke csökken, a másodlagos nemi jellegnek megfelelő testszőrzet és testalkat alakulhat ki. A hormonpótlás hatással van a hímvessző fejlődésére, azonban nincs befolyással a herék méretére és az infertilitásra. Adoleszcens korban bizonyos esetekben megkísérelhetó hímivarsejt nyerése mikrosebészeti módszerrel [30]. Ezzel az eljárással in vitro fertilizáció végezhető, ekkor azonban fennáll a kromoszóma-rendellenesség továbbörökítésének kockázata. A diagnózis felállításakor tapasztalható átlagéletkor, azaz 10 év a tesztoszteronpótlás tekintetében optimális időpont. Tünetek hiányában azonban ebben az életkorban a betegek ritkán kerülnek az orvosok látóterébe, és kevesen részesülhetnek kezelésben. A terápia elmaradása nemcsak pszichésen ró nagyobb terhet az érintettekre, hanem befolyásolja későbbi egészségüket és életminőségüket is. Az időben történő felismeréssel a beteget és szüleit felkészíthetjük a pubertáskori gondokra és a családalapítással járó nehézségekre.

Mindemellett fontos, hogy a nagyobb cardio- és cerebrovascularis, trombotikus, illetve metabolikus megbetegedési rizikó [31] mérséklése érdekében tartsuk szem előtt a minél korábbi prevenciót. Az X-kromoszóma-többlettel járó kórképben a centrális típusú elhízás és az ahhoz gyakran társuló anyagcserezavarok - mint a hyperlipidaemia, az inzulinrezisztencia, a csökkent glükóztolerancia, a kettes típusú cukorbetegség - kombinált terápiával megelőzhetők és gyógyíthatók. A csökkent inzulinérzékenység mérséklésében a megfelelő diéta és testmozgás alapvető, ami felnőttkorban szükség esetén metformin és liraglutid adásával egészíthető ki [32]. A metabolikus zavarok rendezése a fokozott trombóziskockázatot is csökkenti.

\section{Tripla-és poli-X-szindróma, dupla- $\Upsilon$-szindróma}

A tripla-X- és a poli-X-szindróma gyakorisága együttesen sem érte el az elvileg azonos számban előforduló duplaY-szindrómáét. Ennek oka lehet a kis esetszám, illetve az enyhe és sokszor észrevétlenül maradó tünetek.

A tripla- és poli-X-, valamint a dupla-Y-szindróma közös vonása, hogy az alig feltûnő fenotípusjegyek mellett csupán a fertilitásra gyakorolt hatásuk lehet kórjelző [33]. A nemi kromoszómatöbblettel járó eltérésekre egyaránt jellemző, hogy a szám feletti kromoszómákkal arányosan a tünetek súlyossága nő.

Mindhárom szindrómára típusos lehet az átlagosnál magasabb termet, ami a szám feletti nemi kromoszómákon lévő SHOX-gén kópiatöbbletével magyarázható [34]. Ezzel szemben ha két allél helyett csupán egy van jelen - mint a Turner-szindrómában -, a testmagasság elmarad az átlagostól [35].

A tripla- és poli-X-szindróma velejárója lehet még a menstruációs ciklus zavara, a korai petefészek-kimerülés, a megkésett beszéd- és mozgásfejlődés, a testszerte jelentkező izomhipotónia, a nyelvi funkciók zavarából adódó tanulási nehézség, az érzelmi labilitás, a viselkedészavar, valamint vese-rendellenesség és epilepszia [36].

A dupla-Y-szindróma ritkán okozhat fertilitási zavart, de járhat a csontok rendellenes fejlődésével, nagyobb kezekkel és lábakkal, beszéd- és mozgásfejlődési elmaradással és viselkedészavarral $[37,38]$.

Egyetlen X-tetrasomiás páciensünknél a szakirodalomból is ismert tünetek voltak megfigyelhetők, mint a generalizált izomhipotónia, az arcdysmorphia és a megkésett beszédfejlődés [39, 40]. 


\section{Egyéb gonáddiszgenezisek}

A Turner-szindrómások mellett az egyéb gonáddiszgenezissel rendelkezők diagnózis idejében rögzített átlagéletkora sem bizonyult optimálisnak a terápia megkezdése és a prevenció szempontjából.

\section{Megelözés}

A korai diagnózis a gonáddiszgenezissel rendelkezőknél a megfelelő nemi identitás kialakítása [41], a zavartalan serdülés biztosítása, valamint a malignus daganat prevenciója miatt nélkülözhetetlen. Az Y-szekvenciát hordozó diszgenetikus gonádok esetében a gonadoblastoma és a dysgerminoma kockázata fokozott (30\% körüli) [42, 43]. Az időben történő preventív gonadectomia csökkenti a morbiditási és mortalitási valószínűségeket. A probléma jelentőségét mutatja, hogy a Turner-szindrómás betegek körében (5\%) molekuláris genetikai vizsgálattal kimutatható valamely Y-kromoszóma-részlet. Éppen ezért gonáddiszgenezis fennállásakor - amennyiben virilisatio figyelhető meg - indokolt a rejtett Y-kromoszóma DNS szekvenciájának szűrése PCR- vagy FISH-módszerrel. A fokozott daganatkockázattal összefüggésbe hozott régiókat tanácsolt PCR-primerekkel (SRY, ZFY, DYZl, DYZ3, DYS132) szürni [44-47]. A látóterünkbe került gyermekek között virilisatio hiányában nem került sor a fenti szekvenciák vizsgálatára.

A betegeknél megfigyelhető volt, hogy a nemi kromoszómaanomáliák korai azonosításában a praenatalis vizsgálóeljárások nagy segítséget jelentettek. Mivel a kromoszóma-rendellenességgel születők többségénél az anyai életkor nem haladja meg a 35. életévet, célszerü a születendő magzat veszélyeztetése nélkül információt nyerni annak fejlődéséről, genetikai állományáról [5]. A noninvazív szûrőmódszerekkel (magzati ultrahangvizsgálat, az anyai szérummarker vagy az anyai vérből izolált magzati sejtek vizsgálata) lehetőség van az emelkedett kockázatú várandósságok azonosítására. A noninvazív praenatalis tesztek alkalmasak az autoszomális triszómiák, a nemi kromoszóma-rendellenességek és a microdeletiók szürésére, azonban ezen eltérésekre vonatkozóan más-más szenzitivitással és specificitással rendelkeznek. A diagnosztikus értékü invazív eljárások (GAC, CVS, CBS, FTS) alkalmazása [5, 48-50] csak a fokozott rizikójú terhességeknél javallott.

Az első genetikai UH-vizsgálatra a várandósság 11 13. hetében kerül sor, ekkor ellenőrzik a tarkóredő vastagságát (NT) és az orrcsont meglétét. Az emelkedett NT (>3 mm) kórjelző lehet autoszomális triszómiákra (Patau-, Edwards-, Down-szindróma), Turner-, Klinefelter-szindrómára és triploidiára, de az esetek 6\%-ában álpozitív. Az orrcsont hiánya Down-szindrómára utalhat, azonban ritkán $(0,3-0,6 \%)$ egészséges magzatokban is megfigyelhető [5].

A második UH-vizsgálat alkalmával, a 18-20. héten a csontos képletek és a belső szervek fejlődését követik nyomon. Ezek eltérései - kiemelten a szívfejlődés rendellenességei - utalhatnak genetikai anomáliákra [5].

$\mathrm{Az}$ első trimeszterben lehetőség van az úgynevezett kombinált teszt elvégzésére, amely az NT mérését tartalmazza az anyai vérból kimutatott szabad $\beta$-hCG és a PAPP-A szérummarkerekkel kiegészítve [5].

Ugyancsak anyai szérummarkereket detektál a második trimeszterben elvégezhető hármas (össz- $\beta$-hCG, AFP, uE3) és négyes (össz- $\beta$-hCG, AFP, uE3, inhA) teszt [5].

Az anyai vérből izolált magzati sejtek DNS-tartalma PCR-technikával felsokszorosítható, ezáltal a magzati kromoszómák szám- és szerkezetbeli eltérései, microdeletiói vizsgálhatók [5].

A nagyobb kromoszómarendellenesség-kockázattal járó várandósságoknál, valamint gyermekeknél megalapozott gyanú esetén javasolt a humángenetikai tanácsadással egybekötött vizsgálat és a szükséges beavatkozások elvégzése. A szempontok páciensenként sajátosak, egyénileg megfontolandók. Akár a szülői életkor, akár a potenciálisan mutagén környezeti hatások jelenléte, a gyermeket vállalók félelme és igényei igen változatos helyzeteket teremthetnek, melyeknél a jól átgondolt, jogi, szakmai és etikai szempontból helytálló eljárás még a tapasztalt szakemberek számára is sokszor nehéz feladatot jelenthet. A betegségek komplexitásához és az ezzel járó felelősség súlyához mérten ezért minden - a pácienssel kapcsolatba kerülő - egészségügyi dolgozó munkája egyformán jelentős a betegellátás és gondozás során.

Anyagi támogatás: A közlemény megírása, illetve a kapcsolódó kutatómunka anyagi támogatásban nem részesült.

Szerzői munkamegosztás: P. É.: A közleményhez szükséges adatok összegyưjitése és kiértékelése, a kapcsolódó szakirodalom felkutatása és összevetése a saját eredményekkel, következtetések levonása, a közlemény ábráinak, táblázatának összeállítása és a közlemény szövegének megírása. L. A., H. I., F. Gy., S. Á.: A közlemény tartalmi és formai követelményeinek ellenőrzése. H. I., F. Gy., S. Á.: A közlemény megírásához kapcsolódó háttérismeretek átadása, a kézirat kiegészítése, lektorálása. A cikk végleges változatát valamennyi szerző elolvasta és jóváhagyta.

Érdekeltségek: A szerzőknek nincsenek érdekeltségeik.

\section{Köszönetnyilvánítás}

Az első szerző köszönetét fejezi ki a pácienseknek és hozzátartozóik nak a kutatómunkában való részvételért és a cikkben közölt adatok felhasználásához való hozzájárulásukért, továbbá a társszerzőknek és a Semmelweis Egyetem II. számú Gyermekgyógyászati Klinika Citogenetikai Laboratóriuma munkaközösségének a közlemény megírásában nyújtott segítségükért. 


\section{Irodalom}

[1] Maródi L. Pediatrics. [Gyermekgyógyászat.] Medicina Könyvkiadó, Budapest, 2014. [Hungarian]

[2] Rimoin DL, Pyeritz RE, Korf B. Emery and Rimoin's principles and practice of medical genetics. Churchill Livingstone, New York, 2002; pp. 1184-1201.

[3] Nielsen J, Wohlert M. Chromosome abnormalities found among 34,910 newborn children: results from a 13-year incidence study in Arhus, Denmark. Hum Genet. 1991; 87: 81-83.

[4] Szabolcs J. Turner syndrome. [Turner-szindróma]. Gyermekgyógy Továbbk Szle. 2017; 22: 110-111. [Hungarian]

[5] Papp Z, Bán Z. Genomics in XXI. century's medicine; Prenatal and pre-implantation diagnostics. [Genomika a XXI. század orvoslásában; Praenatalis és preimplantációs diagnosztika.] Magy Tud. 2006; 3: 322-329. [Hungarian]

[6] Méhes K, Kosztolányi Gy. A precise description of the phenotype: The contribution of the clinician to clarifying genotypephenotype correlations. [A fenotípus pontos leírása: A klinikus hozzájárulása a genotípus-fenotípus összefüggések tisztázásához.] Orv Hetil. 2006; 147: 1059-1061. [Hungarian]

[7] O'Connor C. Karyotyping for chromosomal abnormalities. Nature Education 2008; 1: 27.

[8] Nussbaum RL, McInnes RR, Willard HF. Thompson \& Thompson Genetics in Medicine. 8th Edition. Cytogenetics and genome analysis. Elsevier Inc., Canada, 2015; 1: 57-59.

[9] Shaffer LG, McGowan-Jordan J, Schmid M. International Standing Committee on Human Cytogenetic Nomenclature 2013: An international system for human cytogenetic nomenclature. Karger, Basel, 2013; pp. 39-104.

[10] Haltrich I, Csóka M, Kovács G, et al. The traditional cytogenetics and FISH are complementary tests in childhood acute lymphoid leukemia. [A hagyományos citogenetika és a FISH egymást jól kiegészítő vizsgálatok gyermekkori akut limfoid leukémiában.] Magy Onkol. 2008; 52: 283-291. [Hungarian]

[11] Bartlett JM. Fluorescence in situ hybridization: Technical Owerview. In: Roulston JE, Bartlett JM. (eds.) Molecular Diagnosis of Cancer, Methods and Protocols. Methods in Moleculat Medicine 2004; pp. 77-87.

[12] Luke S, Shepelsky M. FISH: recent advantages and diagnostic aspects. Cell Vis. 1998; 5: 49-53.

[13] Hungarian Society of Obstetrics and Gynaecology. Developmental disorders of the genital system. In: A Guide to Obstetrics and Gynecology. [Magyar Nőorvos Társaság. A genitális rendszer fejlődési rendellenességei. In: Szülészeti és Nőgyógyászati Útmutató.] Medition Kiadó, Budapest, 2008; p. 3. [Hungarian]

[14] Haltrich I. Phenotypic-genotypic correlations of the Y chromosome structural abnormalities. [Az Y kromoszóma szerkezeti rendellenességeinek genotípus-fenotípus összefüggései.] Magy Belorv Arch. 2012; 5: 304-311. [Hungarian]

[15] Úffalusi A. The genetic background of Turner syndrome. [A Turner-szindróma genetikai háttere]. Gyermekgyógy Továbbk Szle. 2017; 22: 106-109. [Hungarian]

[16] Jørgensen KT, Rostgaard K, Bache I, et al. Autoimmune diseases in women with Turner's syndrome. Arthritis Rheum. 2010; 62: 658-666.

[17] Hosszú É. Skeletal aspects of Turner syndrome. [A Turner-szindróma csontvonatkozásai.] Gyermekgyógy Továbbk Szle. 2017; 22: 112-116. [Hungarian]

[18] Sánchez Marco SB, de Arriba Muñoz A, Ferrer Lozano M, et al. Human growth hormone and Turner syndrome. Anal Pediatr. 2017; 86: 81-86

[19] Sallai Á. Child and adolescent care of Turner syndrome patients, handing over to adult care. [Turner-szindrómás betegek gyermek- és ifjúkori ellátása, átadás a felnőtt gondozásba.] Családorv Fór. 2007; 2: 35-40. [Hungarian]
[20] López MN, Errasti AT, Santiago E. Estrogens and feminine brain maturation during adolescence: emergency contraceptive pill. Cuad Bioet. 2011; 22: 185-200.

[21] Lepage JF, Mazaika PK, Hong DS, et al. Cortical brain morphology in young, estrogen-naive, and adolescent, estrogen-treated girls with Turner syndrome. Cereb Cortex 2013; 23: 21592168.

[22] Bernard V, Donadille B, Zenaty D, et al. Spontaneous fertility and pregnancy outcomes amongst 480 women with Turner syndrome. Hum Reprod. 2016; 31: 782-788.

[23] Chetty S, Norton ME. Obstetric care in women with genetic disorders. Best Pract Res Clin Obstet Gynaecol. 2017; 42: 8699.

[24] Elkayam U, Goland S, Pieper PG, et al. High-risk cardiac disease in pregnancy. J Am Coll Cardiol. 2016; 68: 502-516.

[25] Boissonnas CC, Davy C, Bornes M, et al. Careful cardiovascular screening and follow-up of women with Turner syndrome before and during pregnancy is necessary to prevent maternal mortality. Fertil Steril. 2009; 91: 929.e5-929.e7.

[26] Bondy CA. Care of girls and women with Turner syndrome: A guideline of the Turner syndrome study group. J Clin Endocrinol Metab. 2007; 92: 10-25.

[27] Szabó T. Nephrological disorders in Turner syndrome. [Nefrológiai rendellenességek Turner-szindrómában.] Gyermekgyógy Továbbk Szle. 2017; 22: 117-118. [Hungarian]

[28] Bird R, Hurren B. Anatomical and clinical aspects of Klinefelter's syndrome. Clin Anat. Wiley Online Library, 2016.

[29] Corona G, Giagulli VA, Maseroli E, et al. Testosterone supplementation and body composition: results from a metaanalysis of observational studies. J Endocrinol Invest. 2016; 39: 967-981.

[30] Plotton I, Brosse A, Lejeune $\mathrm{H}$, et al. Infertility treatment in Klinefelter syndrome. Gynecol Obstet Fertil. 2011; 39: 529532.

[31] Calogero AE, Giagulli VA, Mongioì LM, et al. Klinefelter syndrome: cardiovascular abnormalities and metabolic disorders. J Endocrinol Invest. 2017; 40: 705-712.

[32] Corona G, Giagulli VA, Maseroli E, et al. Therapy of endocrine disease: testosterone supplementation and body composition: results from a meta-analysis study. Eur J Endocrinol. 2016; 174: R99-R116.

[33] Van Batavia JP, Kolon TF. Fertility in disorders of sex development: A review. J Pediatr Urol. 2016; 12: 418-425.

[34] Ottesen AM, Aksglaede L, Garn I, et al. Increased number of sex chromosomes affects height in a nonlinear fashion: a study of 305 patients with sex chromosome aneuploidy. Am J Med Genet A 2010; 152A: 1206-1212.

[35] Genoni G, Monzani A, Castagno M, et al. Improving clinical diagnosis in SHOX deficiency: the importance of growth velocity. Pediatr Res. 2018; 83: 438-444.

[36] Butnariu L, Rusu C, Caba L, et al. Genotype-phenotype correlation in trisomy X: a retrospective study of a selected group of 36 patients and review of literature. Rev Med Chir Soc Med Nat Iasi 2013; 117: 714-721.

[37] Jo WH, Jung MK, Kim KE, et al. XYY syndrome: a 13-year-old boy with tall stature. Ann Pediatr Endocrinol Metab. 2015; 20: 170-173.

[38] Scheidt L, Sanabe ME, Diniz MB. Oral, physical, and behavioral aspects of patient with chromosome 47,XYY syndrome. J Indian Soc Pedod Prev Dent. 2015; 33: 347-350.

[39] Berkeley MI, Faed MJ. A female with the 48, XXXX karyotype. J Med Genet. 1970; 7: 83-85.

[40] Peña SD, Ray M, Douglas G, et al. A 48,XXXX female. J Med Genet. 1974; 11: 211-215.

[41] Wolffenbuttel KP, Hersmus R, Stoop H, et al. Gonadal dysgenesis in disorders of sex development: Diagnosis and surgical management. J Pediatr Urol. 2016; 12: 411-416.

[42] Huang H, Wang C, Tian Q. Gonadal tumour risk in 292 phenotypic female patients with disorders of sex development contain- 
ing Y chromosome or Y-derived sequence. Clin Endocrinol. 2017; 86: 621-627.

[43] Tobisch B. Occurrence of gonadoblastoma in Turner syndrome. [A gonadoblastoma előfordulása Turner-szindrómában.] Gyermekgyógy Továbbk Szle. 2017; 22: 119-120. [Hungarian]

[44] Sallai Á, Ugocsai P, Halász Z, et al. Screening of DNA sequences of Y chromosome in Turner syndrome. [Y-kromoszóma DNSszekvenciáinak szűrése Turner-szindrómában.] Gyermekgyógyászat 2006; 57: 409-417. [Hungarian]

[45] Sallai Á, Sólyom J, Dobos M, et al. Y-chromosome markers in Turner syndrome - screening of 130 patients. J Endocrinol Invest. 2010;33: 222-227.

[46] Gravholt CH, Fedder J, Naeraa RW, et al. Occurrence of gonadoblastoma in females with Turner syndrome and $\mathrm{Y}$ chromosome material: a population study. J Clin Endocrinol Metab. 2000; 85: 3199-3202.

[47] Gravholt CH, Andersen NH, Conway GS, et al. Clinical practice guidelines for the care of girls and women with Turner syn- drome: proceedings from the 2016 Cincinatti International Turner Syndrome Meeting. Eur J Endocrinol. 2017, 177: GlG70.

[48] Nagy B, Lázár L, Rigó J Jr. (eds.) Prenatal molecular genetics. [Prenatális molekuláris genetika.] Semmelweis Kiadó, Budapest, 2011. [Hungarian]

[49] Tepperberg J, Pettenati MJ, Rao PN, et al. Prenatal diagnosis using interphase fluorescence in situ hybridization (FISH): 2 -year multi-center retrospective study and review of the literature. Prenat Diagn. 2001; 21: 293-301.

[50] Ward BE, Gersen SL, Carelli MP, et al. Rapid prenatal diagnosis of chromosomal aneuploidies by fluorescence in situ hybridization: clinical experience with 4,500 specimens. Am J Hum Genet. $1993 ; 52$ : 854-865.

(Haltrich Irén dr., Budapest, Tűzoltó u. 7-9., 1094 e-mail: haltrich.iren@med.semmelweis-univ.hu)

\section{NOTA}

\section{Új fejlesztés az egészségügyben dolgozók, tanulók részére!}

\section{A magyar nyelvứ szakirodalmi keresőszolgáltatás}

Mi a NOTA?
Napivizit Orvosi Tudástár Alkalmazás
Mit tud a NOTA portál?
Megkönnyíti a magyar nyelvü
szakirodalmi források keresését.
Eszköztől függetlenül, akár
okostelefonról, a betegágy mellett
állva is használható.

\section{nota.hu}

\section{en} Miben kereshet a NOTA-val?

Az Akadémiai Kiadó folyóirataiban: Orvosi Hetilap, Magyar Sebészet, Mentálhigiéné és Pszichoszomatika.

Más kiadók magyar nyelvủ szakfolyóirataiban: pl. Lege Artis Medicinae, Hypertonia és Nephrologia, deggyógyászati Szemle.

A hatályos szakmai irányelvekben. Magyar nyelvű kérdésekre adott ango
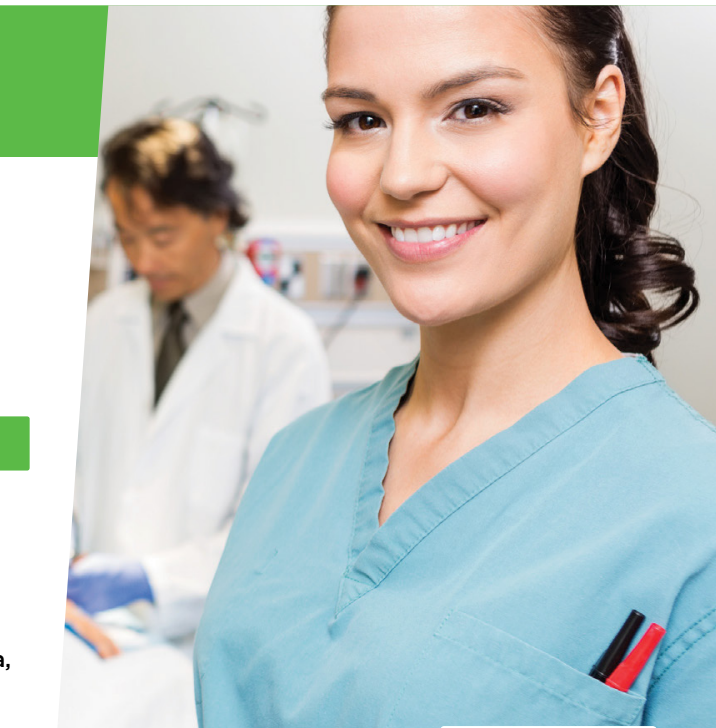

Akadémiai Kiadó

A Wolters Kluwer Csoport tagja

1117 Budapest, Prielle Kornélia u. 21-35. / Telefon: (1) 464-8246

www.akademiai.hu / www.akademiai.com

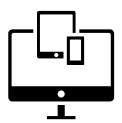

